\title{
Anaerobic Digestion of Waste Organic Matter and Biogas Production
}

\author{
Nabila Laskri, Oualid Hamdaoui, and Nawel Nedjah
}

\begin{abstract}
We are interested in carrying out the process called anaerobic digestion of two different substrates: the biodegradable waste from landfill and sludge from the wastewater treatment plant by natural lagoon. The experiment is performed in a digester with a capacity one liter, sealed. To optimize the degradation of organic matter, we followed the evolution of the degradation of organic matter by measuring the CDO, the volume of biogas formed during the digestion, the temperature and the $\mathrm{pH}$ of the process. We found that the sludge off the wastewater treatment plant by natural lagoon is very rich in fermentable and biodegradable organic material than the proportion of fermentable material of the landfill. The biogas formed is flammable, so very rich in methane.

The volume of biogas produced during the digestion of sludge is greater than 10 times compared with the digestion of organic matter in the landfill. Knowing beforehand that the volume of biogas produced is always a function of the residence time of digestion and the concentration of organic matter.
\end{abstract}

Index Terms-Methanogenesis, organic matter, anaerobic digestion, biogas, sludge.

\section{INTRODUCTION}

New energy sources will have as main feature almost zero $\mathrm{CO}_{2}$ balance [1]. Among them, the ways of bioenergy from waste are particularly interesting. The use of renewable energy, such as biogas, has become a necessity and an integral part of the current strategy to mobilize all available resources.

The anaerobic digestion is a series of operations biological degradation of organic matter by microbial flora that occur in the absence of oxygen. The products of degradation can be classified into two categories: biogas and digestate. Biogas is a mixture of methane $\left(\mathrm{CH}_{4}\right)$, carbon dioxide $\left(\mathrm{CO}_{2}\right)$ and water vapor $\left(\mathrm{H}_{2} \mathrm{O}\right)$. Methane is the main component of natural gas. Digestate is the liquid residue containing non-degraded materials.

The proceeds from the anaerobic digestion are carried out in four stages [2]. These are the following steps:

1) Hydrolysis: macromolecules are cut gradually soluble monomers by extracellular enzymes (cellulases, hydrolases, amylases, etc. ...).

2) Acidogenesis: monomers derived from the hydrolysis step, are converted to organic acids and alcohols with a release ammonium $\left(\mathrm{NH}_{4}^{+}\right)$, carbon dioxide $\left(\mathrm{CO}_{2}\right)$ and hydrogen

Manuscript received April 27, 2014; revised June 30, 2014.

Nabila Laskri and Nawel Nedjah are with the Preparatory School Science and Technology. Annaba, Algeria (e-mail: laskri_n@yahoo.fr, nedjah_nawel@yahoo.fr).

Oualid Hamdaoui is with the University Badji Mokhtar Faculty of Engineering Sciences, Laboratory of Environmental Engineering, Annaba, Algeria (e-mail: ohamdaoui@yahoo.fr).
$\left(\mathrm{H}_{2}\right)$.

3) Acetogenesis: the products of acidogenesis are converted into acetic acid $\left(\mathrm{CH}_{3} \mathrm{COOH}\right)$, but also $\mathrm{CO}_{2}$ and $\mathrm{H}_{2}$, the main substrates of methanogenesis.

4) Methanogenesis: final step in which the methane is formed as two separate channels and main, the acetate and the mixture of $\mathrm{H}_{2} / \mathrm{CO}_{2}$.

In this work, we are interested in biogas production using two different substrates: organic waste in a landfill and sludge from a municipal wastewater by natural lagoon treatment plant.

\section{MATERIALS AND METHODS}

The experiments of anaerobic digestion of two organic substrates are carried out using an experimental device as shown in Fig. 1, consists of:

1) Digester with a capacity of $1 \mathrm{~L}$ equipped with a sampling,

2) Water bath set to the temperature at $37^{\circ} \mathrm{C}$,

3) System for measuring the volume of gas produced (volume measurement by the method of the displaced liquid) [2].

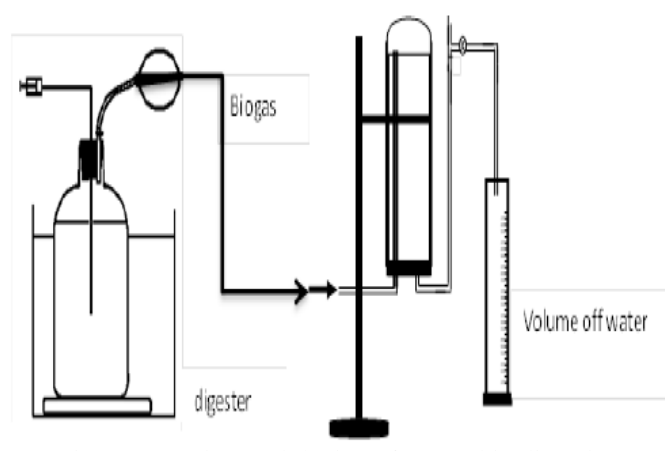

Fig. 1. Experimental device of anaerobic digestion

The parameters monitored during the anaerobic digestion of substrates are $\mathrm{pH}$, temperature, the volume of biogas produced and the chemical oxygen demand CDO.

The volume of biogas produced is measured by connecting the recovery flask connected to a digester with water bottle as the gas moves the fluid to the measuring cylinder.

The anaerobic conditions must be controlled very strictly in the digester before the start of the digestion reaction waste. The experiments are conducted for residence time of 20 to 30 days.

\section{A. Substrates}

\section{1) Organic matter of landfill waste (dump)}

Energy recovery of $40 \%$ of municipal waste can save $6 \%$ on the fuel bill. It is also $6 \%$ saving on the resources of the 
planet [3]. If only we produce heat, the waste heat from 7 to 14 families heats one family. And if only we produce electricity, waste feed from 10 families in electricity powered one family. Energy recovery from waste is used to produce energy in the form of heat or electricity.

According to the National Waste Agency NWA [4], 8.5 million tons of waste of which 1.5 million of industrial origin is emitted annually in Algeria or $0.75 \mathrm{~kg}$ per day per capita. There are 3000 dumps in Algeria, occupied 150 ha. 760,000 tons of wastes are likely to be valued. A study of NWA chows that from this quantities of wastes we found:

1) 1 ton of recycled steel

2) 1 ton of recycled ore

3) 1 ton of recycled paper

4) 2 tons of wood

5) 1 ton of recycled plastic bottles

Organic waste, especially when they have a high water content, are not intended to be stored in landfills, or even be incinerated. It thus requires a strong limitation of the landfill of biodegradable waste [5]. This objective requires significant efforts include: reducing waste, increasing the recycled hand and development of composting, anaerobic digestion followed or not. The important treatment of this organic matter is the recovery to energy from waste through anaerobic digestion process. It is a renewable energy source as we produce waste, the cost is low.

TABLE I: SPECIATION OF LANDFILL WASTE

\begin{tabular}{|c|c|c|c|c|c|}
\hline \multirow[t]{2}{*}{ Comp (\%) } & \multicolumn{4}{|c|}{ Sampling Site } & \multirow[t]{2}{*}{ Moy } \\
\hline & 1 & 2 & 3 & 4 & \\
\hline Organic matter & 63,00 & 55,00 & 72,00 & 57,3 & 61,86 \\
\hline Plastic & 12,00 & 9,66 & 11,34 & 9,00 & 10,50 \\
\hline $\begin{array}{l}\text { Cardboard and } \\
\text { paper }\end{array}$ & 7,66 & 26,00 & 6,33 & 6,33 & 11,58 \\
\hline Metals & 13,00 & 7,66 & 7,33 & 7,00 & 8,75 \\
\hline Glass & 3,60 & 0,68 & 2,33 & 11,30 & 4,50 \\
\hline Rags and other & 0,60 & 1,00 & 0,61 & 9,00 & 2,83 \\
\hline
\end{tabular}

Samples are taken from several sites in the landfill. The sample weight is $20 \mathrm{~kg}$ of mixed household waste. After sorting, we weighed and selected each component of the sample. Speciation samples landfill is gathered in Table I. From the results of this table, it is important to note that the percentage of fermentable organic matter which can be transformed is predominant.

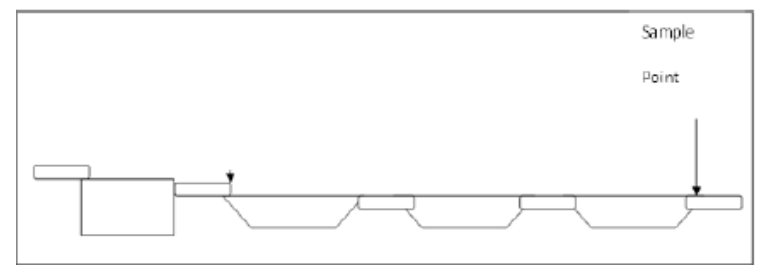

Fig. 2. Sampling point of waste water.

\section{2) Sludge treatment plant}

Sludge from the treatment plant wastewater stabilization ponds are removed from the settling tank 3 as shown in Fig. 2. The natural lagoon is the most widely used biological treatment stations for medium-sized (more than 2000 inhabitant equivalents). The physico-chemical characteristics of the sludge are reported in Table II.
TABLE II: PHYSICAL AND CHEMICAL CHARACTERISTICS OF THE SLUDGE

\begin{tabular}{ll} 
Dry Matter (\% DM) & $5-18$ \\
Dry Volatils Matter (\% DVM) & $60-80$ \\
Azote (\% DM) & $1-4$ \\
Phosphorus (\% DM) & $0,1-1,2$ \\
$\mathrm{CDO}$ : chemical demand in oxygen (mg/L) & $500-1500$ \\
$\mathrm{BDO}_{5}$ : biological demand in oxygen(mg/L) & $160-750$ \\
$\mathrm{pH}$ & $5-8$ \\
\hline
\end{tabular}

\section{3) Chemical analyses}

A representative sample of the substrate is taken each time to perform chemical analysis. The physico chemical analyses used are:

a) Measurement of the $\mathrm{pH}$

The measurement of $\mathrm{pH}$ is done directly by reading on a $\mathrm{pH}$-meter to combined electrode.

\section{b) Dry Matter (\%)}

The measure must be determined as quickly as possible, to limit the losses through evaporation. The standardized method Afnor NF U 44-171, consists of a levy of a maximum quantity of sample, preferably a mass greater than $100 \pm 0.1 \mathrm{~g}$, placing in the oven at $105 \pm 2{ }^{\circ} \mathrm{C}$ until constant weight, approximately 24 hours. The dry matter (MS \%) is the supplementary rate degree of humidity.

c) Dry volatile Matter (\%)

A mass around $50 \pm 0.1 \mathrm{~g}$ is placed at $550{ }^{\circ} \mathrm{C}$, for 2 hours in a furnace (NF U 44- 160).

\section{d) Determination of the chemical oxygen demand (COD)}

Measurement by spectrophotometry UV-VIS [6].

e) Measurement of the NTK (Nitrogen Kjeldahl)

$5 \mathrm{ml}$ of the sample are place in the flask of Kjeldhal.

Add 7, $5 \mathrm{~g}$ of catalyst $\left(\mathrm{CuSO}_{4}+\mathrm{K}_{2} \mathrm{SO}_{4}\right)$. Add $10 \mathrm{ml}$ of $\mathrm{H}_{2} \mathrm{SO}_{4}$.

\section{f) Measurement of the biochemical oxygen demand (BOD)}

The value of this measure allows you to assess the amount of oxygen that the environment must be able to provide to ensure the aerobic degradation of the effluent which is will to be rejected. Measurement of the oxygen consumed in five days by a sample diluted with saturated water into oxygen, sown with the seeds, and then placed in a thermostatic chamber at $20^{\circ} \mathrm{C}$ [7].

Special equipment:

- Glass bottles with ground glass stopper of 150 or $250 \mathrm{ml}$

- Glass bottle thermostatic at $20^{\circ} \mathrm{C}$.

- Equipment necessary for the determination of dissolved oxygen using oximetry equipment.

\section{RESULTS AND DisCUSSION}

\section{A. Anaerobic Digestion of Waste from Landfill}

The anaerobic digestion of organic waste from the landfill is carried out in a digester with a capacity of $1 \mathrm{~L}$. The organic waste is shredded and finely divided into small pieces. The dilution ratio is used by $80 \%$. We followed the $\mathrm{pH}$, temperature, $\mathrm{CDO}$ and measured the volume of the recovered 
biogas which is passed through a Bunsen burner to examine its flammability.

The evolution of the volume of biogas formed during the anaerobic digestion of organic materials from the landfill over time is shown in Fig. 3. From this figure, it appears that the amount of biogas formed increases with increasing residence time in the digester. These results clearly show that methanogen bacteria convert organic matter into biogas.

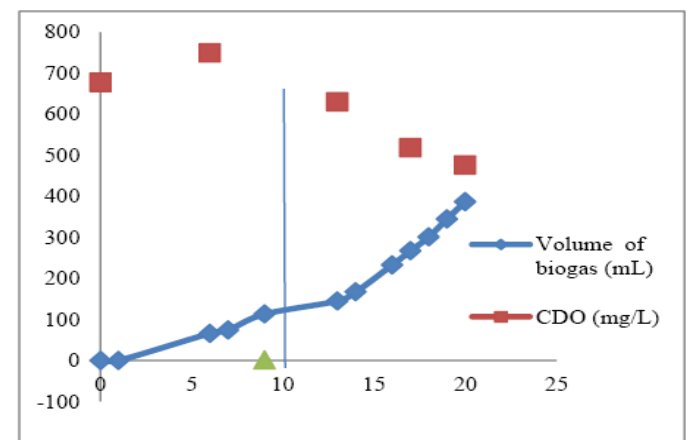

Fig. 3. Evolution of the organic load and volume of biogas formed during the digestion of organic matter in the landfill.

We note from Fig. 3 that becomes flammable biogas from 9èmr days of digestion, neutral $\mathrm{pH}$ around 7 , and the degradation of organic matter is more readable because the curve corresponding to the evolution of CDO begins to decrease. Methanogenesis phase has not been inhibited by the AGV (volatil fat acid), and $\mathrm{NH}_{4}{ }^{+}$. We notice a slight decrease in the $\mathrm{pH}$ of the first day of the digestion until the fifth day of digestion when the $\mathrm{pH}$ was lowered from 8.01 up to 6.76 as shown in Fig. 4, when the $\mathrm{pH}$ increases this tells us that acidogénège phase is exceeded and the degradation of organic matter during methanogenesis and which is reflected in the production of biogas. The temperature during digestion was maintained around $35^{\circ} \mathrm{C}$.

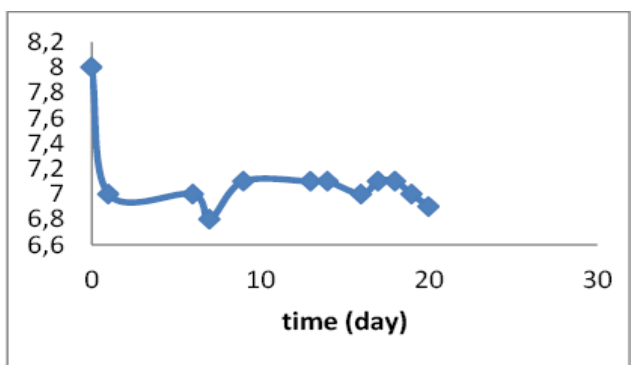

Fig. 4. Change in $\mathrm{pH}$ during the digestion of organic matter in the landfill.

\section{B. Anaerobic Digestion of Sewage Sludge}

The anaerobic digestion of sludge from the treatment plant by natural lagoon is performed using a substrate concentration of $100 \mathrm{~g} / \mathrm{L}$. The evolution of the volume of biogas formed and degradation of the organic load of the sludge are exposed in Fig. 5. We note a production of biogas from the 2 nd day of anaerobic digestion and this is the very necessarily in that biodegradable sludge character. We also note that the sludge treatment plants are more productive in the landfill biogas. This is evidenced by the volume of biogas produced during each experiment. The anaerobic digestion degrades the organic matter in the sludge produced efficiently a flammable biogas. Thus, the more sludge is loaded with organic matter; the more methane will be effective.

We note that the anaerobic digestion with the substrate as sludge from sewage treatment plants is readily biodegradable and form of biogas from the 2 nd day of the process.

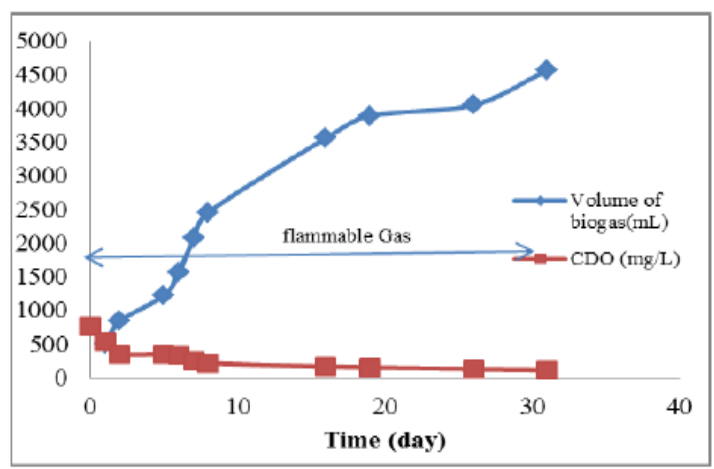

Fig. 5. Evolution of the volume of biogas and CDO of sludge during anaerobic digestion.

Sludge from sewage treatment plants gives a very good performance in biogas production. This is inevitably the biodegradable nature of the sludge. The volume produced is ten times more than the experience of the anaerobic digestion of organic waste from the landfill. The $\mathrm{pH}$ does not decrease significantly from 7.17 to 6.68 which as is shown in Fig. 6, biology and biodegradability of sludge from municipal wastewater anaerobic digestion makes them easy to do.

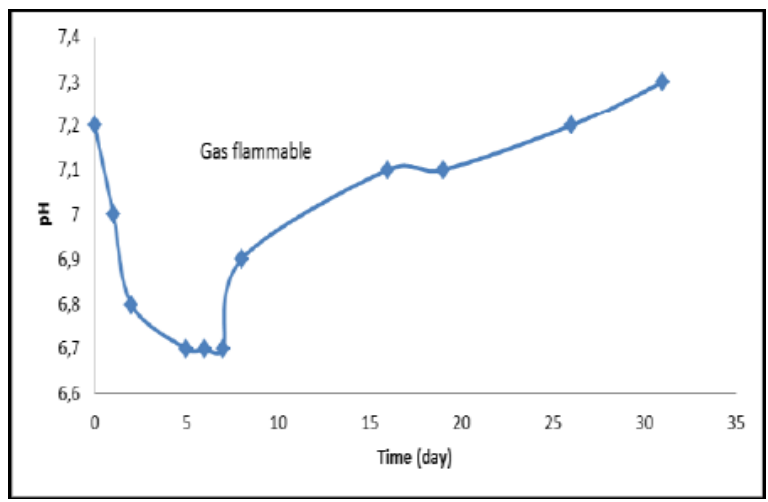

Fig. 6. Evolution of $\mathrm{pH}$ during the anaerobic digestion of sludge.

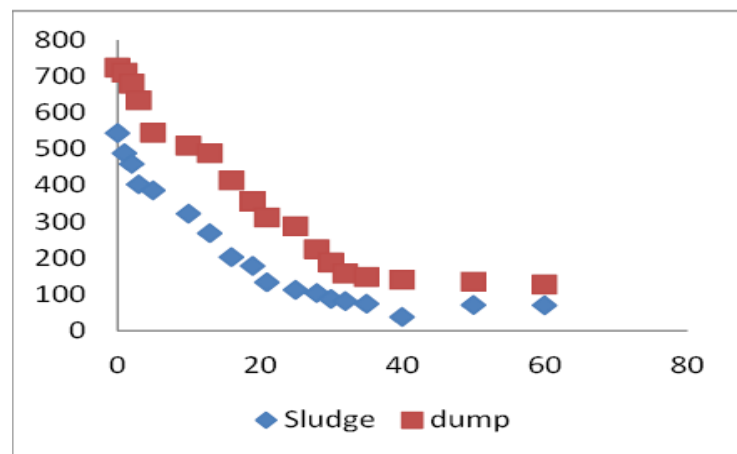

Fig. 7. Comparison of the degradation of organic matter of the two substrates.

If we compare the test anaerobic digestion of two substrates, we note that for the substrate resulted in the production of biogas which\% $\mathrm{CH}_{4}$ is greater than $70 \%$ [8]. This was confirmed by the flammability of biogas produced. It was also noted that the sludge treatment plants are more productive in the landfill biogas. We realized this fact, a comparison 
experiment between the two substrates digestion which was launched in the same operating conditions two anaerobic digestion tests, one with the sewage sludge and other organic waste with the landfill. We followed the variation of CDO and we measured the volume of biogas each bottle. Fig. 7 shows the degradation of the two substrates and indicates that both substrates digestion are biodegradable and can be valuable in a renewable and inexhaustible.

\section{CONCLUSION}

The rate of reduction in of substrate sludge was estimated at $82.44 \%$ and the substrate of the landfill is $87.3 \%$. The biogas produced in the two substrates is flammable, especially since the second day of the digestion of the substrate sludge. Substrate for the landfill, the onset of methanogenesis is detected on day 9. Phase methanogenesis was not inhibited the $\mathrm{pH}$ decreased to 6.68 for the substrate of the discharge for the substrate and 6.76 for sludge off waste water treatment. This slight decrease in $\mathrm{pH}$ shows that the substrate used for the two tests is readily biodegradable. Digestion temperature remains between $35^{\circ} \mathrm{C}$ and $37^{\circ} \mathrm{C}$. The anaerobic digestion process offers the possibility of combining the treatment of waste and the production of renewable energy is biogas rich in methane $\mathrm{CH}_{4}$. The volume of biogas produced during the digestion of sludge of waste water $(5000 \mathrm{~mL}))$ is greater than 10 times compared with the digestion of organic matter in the landfill waste $(500 \mathrm{~mL})$ in the time of digestion 30 days.

Methanogenesis and final phase is the specific step of the methane fermentation. It leads to the reduction of carbon in methane and is carried out by highly specialized microorganisms. During this phase, the chemical oxygen demand decreases to produce biogas against party over the substrate is concentrated biodegradable organic material the more it produces biogas and this was confirmed by comparing the two types of substrate digestion in our study.

\section{REFERENCES}

[1] A. Demayer, La Conversion Bioenergetique, Tec Et Doc, 1982, pp. 214-220.

[2] R. Scriban, Biotechnologie, $4^{\text {th }}$ éd., Tec Et Doc, pp. 701-707.

[3] M. Murat, Valorisation Des Déchets et Des Sous-produits Industrials, Dunod, 1997.

[4] J. Bourgois, B. Debray, and V. Laforest, "Traitements chimiques et physico-chimiques des déchets," Techniques de l'Ingénieur, 1990.

[5] P. Gautron, "Valorisation et recyclage des déchets," Techniques de l'Ingénieur, 1990.

[6] O. Thomas and N. Mazas, "La mesure de la demande chimique en oxygène dans les milieux faiblement pollués," Analusis, vol. 14, pp. 300-302, 1986.
[7] O. Degremont, Mémento Technique De L'eau, Lavoisier, 9th ed., 2002.

[8] I. Tou, S. I. Goud, and A. Touzi, "Production de biométhane à partir des déjections animales," Revue des Energies Renouvelables, 2001, pp. 103-108.

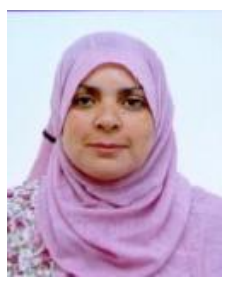

N. Laskri was born on November 20, 1969 in Annaba, Algeria. She was a state engineer in chemical engineering since 1995. She holds a magister degree in chemical engineering in 2000 at the Department of Process Engineering and currently she is conducting her $\mathrm{PhD}$ studies.

From 2003 to 2012, she occupies the position of a professor at the Preparatory School of Sciences and Technology- Annaba, Algeria.

She had participated in the $2^{\text {nd }}$ International Conference on Nano and Materiel Engineering, Dubai 2014. She also had communicated in the International Conference on Energy and Development ICESD 2011, Adrar, and another participation in International Conference on Wastes, Tlemcen 2010 .

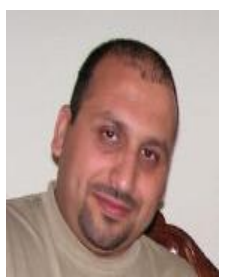

O. Hamdaoui was graduated with engineering degree at the Department of Process Engineering, University of Annaba and received his magister degree and $\mathrm{PhD}$ degree at the same department in 1997 and 2004 respectively, in HDR, habilitation to direct research, process engineering, in 2005.

$\mathrm{He}$ is working as a senior lecturer at the Process Engineering Department since 2005. He is a member of the Laboratory of Molecular Chemistry and Environment, University of Savoie, France as well as a conference session chair and technical review committee.

He had been awarded for the best scientific publication in 2008, (ANDRU), by Ministry of Higher Education and Scientific Research, Algeria.

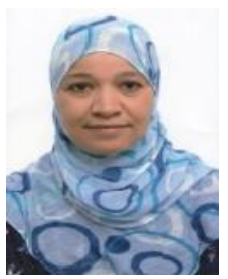

N. Nedjah was born on December 29, 1970 in Annaba, Algeria. She holds a magister degree in chemical engineering in 2002 at the Department of Process Engineering and currently she is conducting her PhD studies.

From 2003 to 2006 she worked as a researcher in renewable energy center, then she moved to the University as a lecturer until to 2012. Now she occupies the position of a professor at the preparatory school of sciences and technologies, Annaba, Algeria.

She had participated in the 2nd International Conference on Nano and Materiel Engineering, Dubai 2014. She also had communicated in the International Conference on Energy and development ICESD 2011, Adrar, and another participation in international conference on wastes, Tlemcen 2010 . 